See Article page 1478.

\section{Commentary: The end of the beginning?}

\author{
Gillian Hardman, MSc, FRCSEd(C-Th), ${ }^{a}$ and \\ John H. Dark, FRCS ${ }^{b}$
}

Winston Churchill's famous phrase "the end of the beginning" aptly describes where we are with the development of a novel and potentially exciting evolution in heart valve technology. In this issue of the Journal, Johnston and colleagues ${ }^{1}$ report on the intermediate-term outcomes from the COMMENCE trial, a prospective, multicenter, singlearm observational study involving 694 patients undergoing surgical aortic valve replacement with a CarpentierEdwards PERIMOUNT Magna Ease aortic valve (Edwards Lifesciences, Irvine, Calif) modified to include RESILIA tissue leaflets (Edwards). It follows on from previous studies of RESILIA tissue, including the same groups' earlier report of 2-year outcomes. ${ }^{2}$ The study is performed to a high standard and provides a model for clinical valve research. Results to support the durability of the valve tissue, here with a median follow-up of 4 years, are encouraging, and, although no comparative analysis is included in the report, outcomes appear similar to those seen in other commercially available aortic bioprostheses.

Aortic valve intervention has undergone significant change during the last decade. The use of mechanical valves has declined, with a marked increase in the number of bioprostheses, most notably in the 55- to 64-year-old age group. ${ }^{3,4}$ In this study, $20.9 \%$ of patients were younger than 60 years. We know that structural valve deterioration (SVD) occurs earlier and progresses more rapidly in younger patients, resulting in a higher lifetime risk of reoperation than with mechanical valves. ${ }^{5}$ For the patient, avoidance of lifelong anticoagulation with warfarin is an attractive prospect, and it has been accompanied by a promise from the physician of future valve-in-valve interventions

\footnotetext{
From the ${ }^{\mathrm{a} D e p a r t m e n t}$ of Cardiothoracic Surgery, Freeman Hospital; and ${ }^{\mathrm{b}}$ Department of Cardiothoracic Surgery, Newcastle University, Newcastle Upon Tyne, United Kingdom.

Disclosures: Authors have nothing to disclose with regard to commercial support.

Received for publication Feb 10, 2020; revisions received Feb 10, 2020; accepted for publication Feb 11, 2020; available ahead of print Feb 19, 2020.

Address for reprints: John H. Dark, FRCS, Cardiothoracic Centre, Newcastle University, Newcastle upon Tyne, NE7 7DN, United Kingdom (E-mail: John.dark@ newcastle.ac.uk).

J Thorac Cardiovasc Surg 2021;162:1489-90

$0022-5223 / \$ 36.00$

Copyright (c) 2020 by The American Association for Thoracic Surgery

https://doi.org/10.1016/j.jtcvs.2020.02.039
}

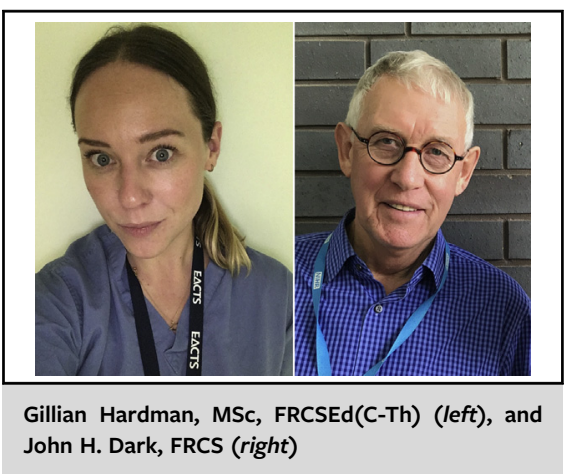

CENTRAL MESSAGE

Good performance and safety of the RESILIA leaflet tissue valve have been confirmed at 4 years. Further follow-up is essential.

should SVD occur. These procedures are not without risk, however, and the development of valve tissue with improved durability and longevity, particular for younger, more active patients, warrants our serious attention.

As Johnston and colleagues ${ }^{1}$ note, it is unlikely that calcific SVD would be identified at 4-year follow-up. The Carpentier-Edwards Perimount pericardial valve used in this study, without the modification of RESILIA tissue leaflets, already has an actuarial freedom from SVD at 15 years of $79 \%$, with an expected valve durability of 19 years. ${ }^{6}$ Follow-up of less than 5-years is therefore of limited value in the assessment of durability of a valve unless unacceptably high rates of early SVD are identified. There must always be caution in extrapolating good early and midterm outcomes to long-term durability.

The absence of noncalcific SVD, with good valve hemodynamics at 4 years, is encouraging, but the true value of this work will lie in long-term follow-up. Further investigation, with similarly high standards for valve assessment and completeness of data, is required to establish the safety and durability of this tissue, particularly in the younger patient age group. Future publications from this study might allow us to glimpse Churchill's next phrase, "the beginning of the end."

\section{References}

1. Johnston DR, Griffith B, Puskas JD, Bavaria JE, Svensson LG, COMMENCE Trial Investigators. Intermediate-term outcomes of aortic valve replacement 
using a bioprosthesis with a novel tissue. J Thorac Cardiovasc Surg. 2021;162: 1478-85.

2. Puskas JD, Bavaria JE, Svensson LG, Blackstone EH, Griffith B, Gammie JS, et al. The COMMENCE trial: 2-year outcomes with an aortic bioprosthesis with RESILIA tissue. Eur J Cardiothorac Surg. 2017;52:432-9.

3. Tam DY, Rocha RV, Wijeysundera HC, Austin PC, Dvir D, Fremes SE. Surgical valve selection in the era of transcatheter aortic valve replacement in the Society of Thoracic Surgeons Database. J Thorac Cardiovasc Surg. 2020;159: 416-27.e8.
4. Goldstone AB, Chiu P, Baiocchi M, Lingala B, Patrick WL, Fischbein MP, et al. Mechanical or biological prostheses for aortic-valve and mitral-valve replacement. N Engl J Med. 2017;377:1847-57.

5. Chiang YP, Chikwe J, Moskowitz AJ, Itagaki S, Adams DH, Egorova NN. Survival and long-term outcomes following bioprosthetic vs mechanical aortic valve replacement in patients aged 50 to 69 years. JAMA. 2014;312:1323-9.

6. Bourguignon T, Bouquiaux-Stablo AL, Candolfi P, Mirza A, Loardi C, May MA, et al. Very long-term outcomes of the Carpentier-Edwards Perimount valve in the aortic position. Ann Thorac Surg. 2015;99:831-7. 